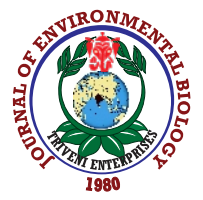

\title{
Planting geometry and nutrient levels affecting seed cotton yield, productivity indices and economic parameters of Bt cotton (Gossypium hirsutum L.)
}

\author{
K. Singh* and P. Rathore \\ Punjab Agricultural University, Regional Research Station, Faridkot-151 203, India \\ *Corresponding Author Email : kulvir@pau.edu
}

\section{Abstract}

Aim: Lack of location specific information on nutrition requirement and planting geometry needs of $B t$ cotton hybrids is creating confusion among farmers. Growing Bt hybrids with traditional knowledge or to try different combinations of nutrition and planting geometries is often non-remunerative. Therefore, studies were initiated to find out the optimum combination of planting geometry and nutritional level for better yield to be advocated among farmers.

Methodology: A field experiment comprising of 4 planting geometries $\left(P G_{1}: 67.5 \mathrm{~cm} \times 60 \mathrm{~cm}, \mathrm{PG}_{2}: 67.5 \mathrm{~cm} \times 75 \mathrm{~cm}, \mathrm{PG}_{3}: 100 \mathrm{~cm} \times 45 \mathrm{~cm}\right.$ and $\mathrm{PG}_{4}: 100 \mathrm{~cm} \times 60 \mathrm{~cm}$ ) in main and 3 nutrient levels $\left\{\mathrm{NL}_{1}: 150: 30: 50: 25\right.$ (N:P:K:Zn in kg ha ${ }^{-1}$ ), $\mathrm{NL}_{2}: 150: 40: 20: 24$ and $\left.\mathrm{NL}_{3}: 175: 60: 60: 25\right\}$ in sub plots of split plot design was conducted during 2016 and 2017 at Faridkot.

Results: Among planting geometries, $\mathrm{PG}_{3}\left(3303 \mathrm{~kg} \mathrm{ha}^{-1}\right)$ recorded the highest seed cotton yield (SCY), while $\mathrm{PG}_{4}\left(2728 \mathrm{~kg} \mathrm{ha}^{-1}\right)$ recorded least despite highest bolls per plant. Though nutrition levels varied non-significantly for $\mathrm{SCY}$, yet $\mathrm{NL}_{2}$ exhibited better fertilizer use efficiency (FUE), i.e., 13.64, indicative of its advantages over $\mathrm{NL}_{1}$ (11.93) and $\mathrm{NL}_{3}(9.77)$.

Interpretation: Thus, based on the present study a PG of $67.5 \times 75 \mathrm{~cm}$ and NL of 150:40:20:24 ( $\mathrm{N}: \mathrm{P}: \mathrm{K}: \mathrm{Zn}$ in $\mathrm{kg} \mathrm{ha}^{-1}$ ) is recommended. Productivity indices as well as economic parameters elucidate that nutrition rates could be further reduced by $86 \mathrm{~kg} \mathrm{ha}^{-1}$ (i.e., 25:20:40:1 $\mathrm{kg}$ of $\mathrm{N}, \mathrm{P}, \mathrm{K}$ and $\mathrm{Zn}$ ) which amount to $33 \$$ ha ${ }^{-1}$ from what farmers $\left(\mathrm{NL}_{3}\right)$ are applying, without any yield loss. Present findings can reduce

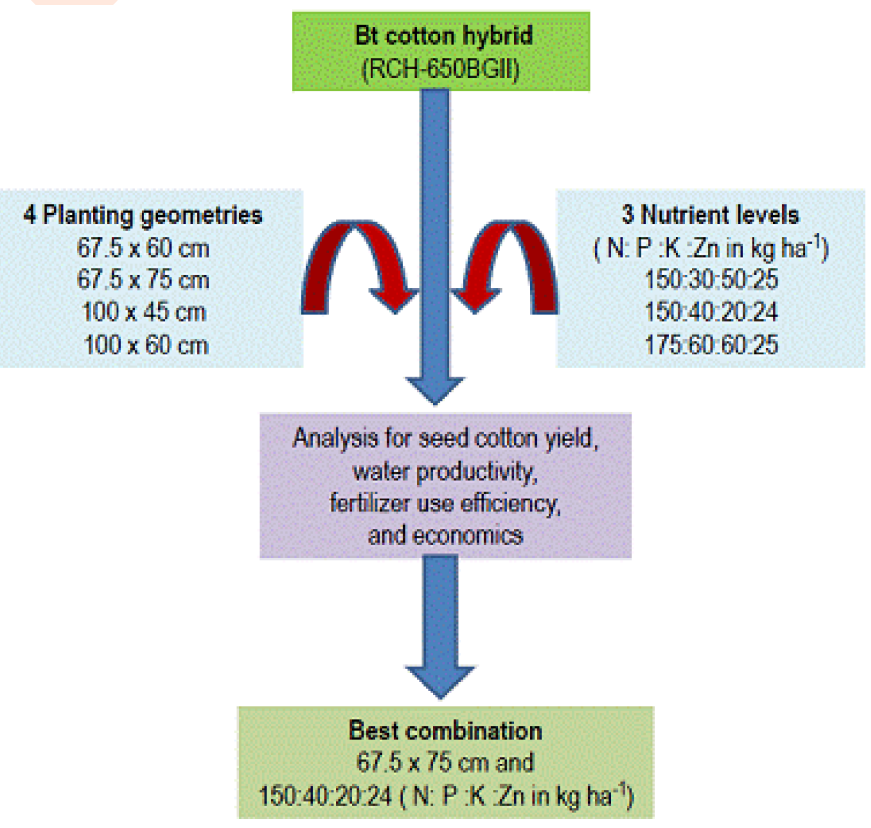
fertilizer cost and could save 0.13 million ton of fertilizer in $\sim 1.54$ million ha of north India alone.

Key words: Apparent water productivity, Fertilizer use efficiency, Nutrition levels, Planting geometry, Seed cotton yield

How to cite : Singh, K. and P. Rathore: Planting geometry and nutrient levels affecting seed cotton yield, productivity indices and economic parameters of Bt cotton (Gossypium hirsutum L.). J. Environ. Biol., 41, 1550-1559 (2020). 


\section{Introduction}

Cotton (Gossypium hirsutum L.) is a major cash crop occupying nearly 33 million ha in 77 countries as a major source of natural fiber worldwide. Though, India is currently the leading cotton producer in the world but due to many constraints, production over year 2016 has increased merely by $5.5 \%$, primarily through more acreage which has increased by $17 \%$ from 10.5 to 12.3 million ha. (Anonymous, 2017). Contrarily, cotton production in China and United States has enhanced by $23 \%$ with only $20 \%$ increase in area as compared to last year. Despite significant reduction of area (-20\%) in Australia over last year, cotton production level has remained unaffected due to increased productivity $\left(2202 \mathrm{~kg} \mathrm{ha}^{-1}\right)$. Poor yield level $\left(<600 \mathrm{~kg} \mathrm{ha}^{-1}\right)$ in India indicates huge gap as compared to developed countries and, thus, necessitate for better production strategies (Singh et al., 2018). Around $65 \%$ of Indian cotton is rainfed, except for north-western India (comprising of states like Punjab, Haryana and part of Rajasthan), where it is primarily cultivated under assured irrigation. Punjab is having fully irrigated area wherein southwestern cotton belt accounts for more than $95 \%$ of state's cotton acreage. Owing to assured irrigation and mechanization facilities, Punjab had earlier remained most productive place for cotton cultivation. However, seed cotton productivity as well as area under cotton during 2015 has shrunk to merely $313 \mathrm{~kg} \mathrm{ha}^{-1}$ from $0.28 \mathrm{~m}$ ha while during 2011, the average productivity was $607 \mathrm{~kg}$ ha $^{-1}$ from an area of $0.56 \mathrm{~m}$ ha (Anonymous 2017).

Presently, Bt cotton covers more than $95 \%$ of total cotton acreage of $\sim 0.3$ million ha in Punjab (Anonymous, 2020). However, few interesting issues are coming with $B t$ cotton cultivation. At present more than $1500 \mathrm{Bt}$ cotton hybrids from more than 50 private companies have been approved for sale and cultivation by the Genetic Engineering Appraisal Committee in merely 17 years from 2002 to 2019 for commercial cultivation across the country. Private sector is releasing innumerable $B t$ hybrids without testing their site-specific agro-ecology. Lack of information on nutrition requirement and planting geometry needs of such released $B t$ hybrids is creating confusion among farmers. Cotton growers find it difficult to select a suitable agronomic package for site-specific agro climatic needs. Under such situations, they either continue to grow Bt hybrids with traditional practices or are persuaded to try different combinations of nutrition levels and planting geometries every year unaware of ideal agronomic requirements (Singh et al., 2014).

This is not only risky but usually unprofitable. Ideal planting geometry, suitable cultivars and optimum nutrition level are major components of any crop production system (Singh et al., 2018). For a crop like cotton, nutrition and plant population assumes greater importance (Dong et al., 2012). Bt cotton hybrids being exhaustive, require ample soil nutrients (Nagender et al., 2017). Moreover, attention for nutrient management is crucial since continuous cropping system is prevalent in northwestern India (Brar et al., 2008). Crop response, soil condition and prevailing cropping patterns affect nutrient recommendation under site-specific conditions (Khan et al., 2017). Dong et al. (2010) reported enhanced seed cotton yield (SCY) with N and K application in soils having poor fertility, while under higher fertility sole $\mathrm{K}$ fertilization can improve productivity. Bt cotton hybrid requires specific crop geometry and optimum fertilization for maximum yield. Standardizing agronomic practices such as optimum planting geometry concurrent with ideal fertilization can exert positive influence on the growth, development and quality parameters of cotton (Shukla et al., 2014; Luo et al., 2018). Adequate planting geometry also prevents inter-plant competition for resources (Zhi et al., 2016). Hence, there is a need to define the crop geometry and nutrient needs of $B t$ cotton hybrids under site-specific conditions so as to realize its full potential. Yield increments under enhanced levels of nutrients in Bt cotton are well documented for central and southern parts of country (Bhalerao and Gaikwad, 2010), but at present, information on ideal planting geometry and optimum nutrient level to achieve potential yield of $B t$ cotton hybrids in north-western India is not fully documented.

Introducing optimal plant densities for better yield can benefit growers and, thus, is of prime importance for guiding the farmers. RCH650 BGIl cotton hybrid though popular among farmers but is being grown at varying planting geometries (PG) and different nutrition levels (NL). Hence, the present study was initiated. Main objectives of this research were to (i) compare growth, SCY and quality parameters of Bt cotton under different planting geometries and varied nutritional levels and (ii) find out the optimum combination of planting geometry and nutritional level for quality seed cotton to be advocated among cotton growers based on productivity indices and economic evaluation.

\section{Materials and Methods}

Weather and climate details: The cotton belt in north-western India is characterized as semi-arid (dry) with $40 \mathrm{~cm}$ annual rainfall, of which $70-80 \%$ is received as monsoonal rains during July to September. The weather data during crop growth period on various agro-meteorological indices recorded from the field observatory of Regional Research Station located 300 m away from the experimental site is presented in Fig. 1.

Experimental site: Field experiments were conducted at 2 different sites during Kharif season of year 2016 and 2017 at Research Station of Punjab Agricultural University, Faridkot, $\left(30^{\circ} 40^{\prime} 31^{\prime \prime} \mathrm{N}\right.$ and $\left.74^{\circ} 44^{\prime} 56^{\prime \prime} \mathrm{E}\right)$, Punjab, India. Site II during second year was selected owing to the fact that after first year cotton experiment at Site I, sugarcane crop was raised during March 2017 and therefore for second season experimentation, a new site was required. This Research Station typically represents Zone IV (South-Western arid zone) of Indian Punjab and northwestern zone of India and is located at $201 \mathrm{~m}$ above MSL. Geologically, Indo-Gangetic alluvial plains with varying monotony of Pleistocene and recent alluvial deposits of the rivers of IndoGangetic system, have constituted this Research station after complete shrouding of the old land surface. 


\section{Soiltype}

Properties of soil

\begin{tabular}{|c|c|c|c|c|c|c|c|}
\hline Year & $\begin{array}{l}\text { Experimental } \\
\text { site }\end{array}$ & $\begin{array}{l}\text { Soil } \\
\text { type }\end{array}$ & $\begin{array}{l}E C \\
\left(d s ~ m^{-1}\right)\end{array}$ & $\begin{array}{l}\mathrm{OC} \\
(\%)\end{array}$ & $\begin{array}{l}P \\
\left(\mathrm{~kg} \mathrm{ha}^{-1}\right)\end{array}$ & $\begin{array}{l}\mathrm{K} \\
\left(\mathrm{kg} \mathrm{ha}^{-1}\right)\end{array}$ & $\begin{array}{l}\mathrm{Zn} \\
\left(\mathrm{kg} \mathrm{ha}^{-1}\right)\end{array}$ \\
\hline 0 & & Loamy 8.6 & $\begin{array}{l}0.27 \\
0.23\end{array}$ & $\begin{array}{l}0.42 \\
0.54\end{array}$ & $\begin{array}{l}9.5 \\
13.1\end{array}$ & $\begin{array}{l}472 \\
578\end{array}$ & $\begin{array}{l}4.85 \\
4.55\end{array}$ \\
\hline
\end{tabular}

As per soil test guidelines of Punjab Agricultural University, the $\mathrm{pH}$ was slightly alkaline with normal $\mathrm{EC}\left(<0.80 \mathrm{ds} \mathrm{m}^{-1}\right)$, low and medium in P during 2016 and 2017 $\left(<22.5 \mathrm{~kg} \mathrm{ha}^{-1}\right)$, while $\mathrm{K}\left(>138 \mathrm{~kg} \mathrm{ha}^{-1}\right)$ and $\mathrm{Zn}\left(>1.5 \mathrm{~kg} \mathrm{ha}^{-1}\right)$ content was high. However, organic carbon $(\%)$ was medium $(0.40-0.75 \%)$

Experimental design and treatment details: The experiment comprising of four planting geometries (i.e. $P \mathrm{G}_{1}: 67.5 \mathrm{~cm} \times 60 \mathrm{~cm}$ [24691 plants ha-1], $\mathrm{PG}_{2}: 67.5 \mathrm{~cm} \times 75 \mathrm{~cm}$ [19753 plants ha' ${ }^{-1}$, $P_{3}: 100 \mathrm{~cm} \times 45 \mathrm{~cm}\left[22222\right.$ plants ha ${ }^{-1}$, and $P_{4}: 100 \mathrm{~cm} \times 60 \mathrm{~cm}$ [16666 plants ha ${ }^{-1}$ ]) in main and three levels of nutrients \{i.e. $\mathrm{NL}_{1}$ : 150:30:50:25 (N: P :K :Zn in kg ha'), $\mathrm{NL}_{2}: 150: 40: 20: 24$ and $\mathrm{NL}_{3}$ : 175:60:60:25\} in sub plots was conducted in Split Plot design replicated thrice. $\mathrm{PG}_{2}$ and $\mathrm{NL}_{1}$ was recommended level for old $B t$ hybrids under cultivation for Punjab state and, thus, considered as standard/control. Among these, $\mathrm{NL}_{1}, \mathrm{NL}_{2}$ and $\mathrm{NL}_{3}$ are recommended nutrient levels the for state of Punjab, Haryana and Rajasthan, respectively which constitute north-western Indian cotton zone. Farmer's often attempt many geometry $X$ nutrition combinations, but above mentioned treatments (planting geometries and nutrient levels) were among major combinations being practiced by growers and identified during field surveillance at farmer's fields across north-western Indian cotton zone. Among these, a combination of $\mathrm{PG}_{4}$ and $\mathrm{Nl}_{3}$ was most dominant at farmer's fields. Therefore, for adhering to a uniform mechanical inter culture practice and best fertilizer dosage in zone, this experiment has been formulated to guide growers.

Methodology and crop management: RCH650 BGII Bt cotton hybrid was sown on May 4, 2016 and May 7, 2017 by dibbling 2 seed per hill in a plot $\left(43.2 \mathrm{~m}^{2}\right)$ though later were thinned to maintain single sapling per hill after first irrigation. $\mathrm{PG}_{1}(67.5 \times 60$ $\mathrm{cm}$ ) implies a distance of $67.5 \mathrm{~cm}$ within rows and an intra row spacing of $60 \mathrm{~cm}$. Required dose of $P$ and $K$ was applied as basal dose by uniform broadcasting during preparation of field prior to sowing, while $\mathrm{N}$ was applied as band application in three equal splits at 40, 70 and 90 days after sowing (DAS).Zinc (21\%) @25 $\mathrm{kg}$ per ha was applied after second irrigation as band application followed by its mechanical soil incorporation after 60 DAS. All other cultural practices and plant protection measures were uniformly applied as per university guidelines. During both years, 5 irrigations ( $75 \mathrm{~mm}$ each) were applied to raise the crop (Singh etal., 2020).

Growth, seed cotton yield and quality parameters: Data on various growth, yield and quality parameters were recorded for studied treatments. Plant height, number of monopods (vegetative branches per plant), sympods (reproductive branches per plant) and mature open bolls per plant at maturity were measured from ten plants per plot selected at random from all three replications. Total number of plants in each plot $\left(43.2 \mathrm{~m}^{2}\right)$ at harvest was counted and constituted plant stand. After second picking, the plants were chopped using sickle from the ground level and kept for 10 days for drying. Their above ground sun dried weight constituted the total biomass accumulation and is expressed in $\mathrm{q} \mathrm{ha} \mathrm{h}^{-1}$. Manual picking of seed cotton was done during October-November months of both study years. Seed cotton yield (SCY) is expressed in $\mathrm{kg} \mathrm{ha}^{-1}$ by cumulating total of two manual pickings from whole plot, excluding the border rows to eliminate border effect. From the second picking, fifty open bolls were selected from each plot to calculate the average weight of bolls. These bolls were sun dried to $\leq 11 \%$ moisture content (Dong et al., 2010) and ginned to work out quality parameters such as lint (\%), seed index and lint index. Lint (GOT \%) was calculated using clean dry seed cotton picked from selected bolls (Khan et al., 2017).

$$
\text { Lint }(\%)=(\text { Weight of lint } / \text { Weight of seed cotton }) \times 100
$$

For seed index, 100 lint free seeds have been weighed after ginning and their weight in gram has been treated as seed index. Lint index represented the weight of lint obtained from one hundred seeds expressed in gram and was calculated as per the formula given below.

\section{Lint index $=($ Seed index $x$ Lint $\%) / 100-$ Lint $\%$}

Lint yield $\left(\mathrm{kg} \mathrm{ha}^{-1}\right)$ has been calculated by multiplying seed cotton of each plot with respective lint (\%) and then divided by 100 . Seed yield $\left(\mathrm{kg} \mathrm{ha}^{-1}\right)$ was calculated by subtracting lint yield from SCY for each treatment.

Computation of water productivity, fertilizer use efficiency and monetary parameters: Apparent water productivity (AWP) was calculated with respect to irrigation water applied during crop growth period (Brar et al., 2012). Gross amount of water delivered for irrigation, throughout seasons was calculated by cumulating total volume of water given in every irrigation including presowing irrigation and was measured with water meter installed at delivery point.

$\operatorname{AWP}\left(\mathrm{kg} \mathrm{m}^{-3}\right)=$ Seed cotton yield $\left(\mathrm{kg} \mathrm{ha}^{-1}\right) /$ Irrigation water $\operatorname{applied}\left(\mathrm{m}^{3} \mathrm{ha}^{-1}\right)$

Fertilizer use efficiency (FUE) = Seed cotton yield $\left(\mathrm{kg} \mathrm{ha}^{-1}\right) /$ fertilizer applied ( $\mathrm{kg} \mathrm{ha}^{-1}$ )

Among, economic parameters, net return per ha was calculated by deducting cultivation cost from gross return. Cost benefit $(\mathrm{C}: \mathrm{B})$ ratio was calculated to evaluate the economic viability of treatments (Singh et al., 2019).

Statistical analyses: Statistical analyses of different recorded parameters were performed to visualize the effect of various treatments. The analysis of variance was conducted using SAS 
software version 9.4 (SAS, 2016 Institute Inc., Cary, NC, USA) for various recorded and computed parameters for individual years separately. There were no difference in the data obtained from the two sites and owing to similar trends in results during study years from both the sites, pooled analysis was performed by taking year as main factor to increase the precision of treatments under study. Since interaction effect (PG x NL) for computed parameters was found to be non-significant, therefore pooled mean of two years for individual parameters have been presented in results and discussion component. Fisher's least significant difference test (LSD) was used to compare the difference between means at $5 \%$ probability level. Difference among studied treatments indicates statistical difference $(L S D=0.05)$.

\section{Results and Discussion}

Introducing optimal plant densities for better yield can benefit growers and, thus, is of prime importance for guiding farmers. Planting geometries significantly affected growth parameters like monopods, sympods and biomass whereas differences for plant height remained trivial (Table 1). Though, $\mathrm{PG}_{4}$ recorded the highest monopods (3.03) and sympods (25.7) per plant as compared to rest of the geometries but on the contrary it also registered significantly least biomass (12.47 $\mathrm{mg} \mathrm{ha}^{-1}$ ) and lowest plant stand. $\mathrm{PG}_{2}$ recorded the highest biomass (15.28 $\mathrm{mg} \mathrm{ha}^{-1}$ ) closely followed by $\mathrm{PG}_{3}$ (14.63 $\mathrm{mg} \mathrm{ha}^{-1}$ ). Data indicated statistically improved bolls per plant under $\mathrm{PG}_{4}$ though boll weight revealed little differences among tested geometries (Table 2). Bolls per plant remained higher for $\mathrm{PG}_{4}$ (72.4) followed by $\mathrm{PG}_{2}$ (65.0), $P \mathrm{G}_{1}$ (59.8) and least under $\mathrm{PG}_{3}$ (58.9). Despite least boll number, seed cotton yield (SCY) remained higher for $\mathrm{PG}_{3}\left(3303 \mathrm{~kg} \mathrm{ha}{ }^{-1}\right)$ and statistically lowest for $\mathrm{PG}_{4}\left(2728 \mathrm{~kg} \mathrm{ha}{ }^{-1}\right)$. Lint and seed yield has been highest for $P_{3}\left(1098 \mathrm{~kg} \mathrm{ha}^{-1}\right)$ and $\mathrm{PG}_{1}\left(2207 \mathrm{~kg} \mathrm{ha}^{-1}\right)$, respectively. Contrarily, reduced seed and lint yield was

Table 1: Growth parameters of Bt cotton (Pooled mean of 2 years)

\begin{tabular}{|c|c|c|c|c|c|}
\hline \multirow[b]{2}{*}{ Nutrition levels (NL) } & \multicolumn{4}{|c|}{ Planting geometry (PG) } & \multirow[b]{2}{*}{ Mean } \\
\hline & $\mathrm{PG}_{1}$ & $\mathrm{PG}_{2}$ & $\mathrm{PG}_{3}$ & $\mathrm{PG}_{4}$ & \\
\hline & \multicolumn{4}{|c|}{ Plant height $(\mathrm{cm})$} & \\
\hline $\mathrm{NL}_{1}$ & 144.5 & 140.2 & 142.5 & 137.8 & 141.2 \\
\hline $\mathrm{NL}_{2}$ & 151.7 & 143.6 & 147.6 & 141.4 & 146.1 \\
\hline $\mathrm{NL}_{3}$ & 151.2 & 145.8 & 149.5 & 142.6 & 147.3 \\
\hline Mean & 149.1 & 143.2 & 146.5 & 140.6 & \\
\hline $\operatorname{LSD}(p=0.05)$ & \multicolumn{4}{|c|}{$\begin{array}{c}P G=N S ; N L=N S ; P G \times N L=N S \\
\text { Monopods plant }{ }^{-1}\end{array}$} & \\
\hline $\mathrm{NL}_{1}$ & 2.67 & 2.78 & 2.50 & 2.94 & 2.72 \\
\hline $\mathrm{NL}_{2}$ & 2.83 & 3.00 & 2.61 & 3.17 & 2.90 \\
\hline $\mathrm{NL}_{3}$ & 2.83 & 2.95 & 2.72 & 2.99 & 2.87 \\
\hline Mean & 2.78 & 2.91 & 2.61 & 3.03 & \\
\hline $\operatorname{LSD}(p=0.05)$ & \multicolumn{4}{|c|}{$\begin{array}{c}P G=0.23 ; N L=N S ; P G \times N L=N S \\
\text { Sympods plant }{ }^{-1}\end{array}$} & \\
\hline $\mathrm{NL}_{1}$ & 20.2 & 22.8 & 21.5 & 24.9 & 22.3 \\
\hline $\mathrm{NL}_{2}$ & 21.3 & 23.5 & 22.5 & 25.3 & 23.1 \\
\hline $\mathrm{NL}_{3}$ & 22.7 & 24.5 & 23.7 & 27.0 & 24.4 \\
\hline Mean & 21.3 & 23.5 & 22.5 & 25.7 & \\
\hline LSD $(p=0.05)$ & \multicolumn{4}{|c|}{$\begin{array}{c}\mathrm{PG}=1.5 ; \mathrm{NL}=1.4 ; \mathrm{PG} \times \mathrm{NL}=\mathrm{NS} \\
\text { Biomass }\left(\mathrm{Mg}^{\left.-\mathrm{ha}^{-1}\right)}\right.\end{array}$} & \\
\hline $\mathrm{NL}_{1}$ & 13.53 & 14.56 & 14.83 & 12.09 & 13.75 \\
\hline $\mathrm{NL}_{2}$ & 14.38 & 15.37 & 14.57 & 12.85 & 14.29 \\
\hline $\mathrm{NL}_{3}$ & 13.79 & 15.91 & 14.51 & 12.47 & 14.16 \\
\hline Mean & 13.90 & 15.28 & 14.63 & 12.47 & \\
\hline $\operatorname{LSD}(p=0.05)$ & \multicolumn{4}{|c|}{$\begin{array}{c}P G=1.07 ; N L=N S ; P G \times N L=N S \\
\text { Plant stand }\left(h^{-1}\right)\end{array}$} & \\
\hline $\mathrm{Nl}_{1}$ & 22872 & 18835 & 21117 & 15752 & 19644 \\
\hline $\mathrm{NL}_{2}$ & 22734 & 19060 & 21064 & 16132 & 19747 \\
\hline $\mathrm{NL}_{3}$ & 22885 & 18886 & 21068 & 15502 & 19585 \\
\hline Mean & 22830 & 18927 & 21083 & 15795 & \\
\hline $\operatorname{LSD}(p=0.05)$ & \multicolumn{4}{|c|}{$P G=563 ; N L=N S ; P G \times N L=N S$} & \\
\hline
\end{tabular}

Note: $P_{G}: 67.5 \times 60 \mathrm{~cm} ; \mathrm{PG}_{2}: 67.5 \times 75 \mathrm{~cm} ; \mathrm{PG}_{3}: 100 \times 45 \mathrm{~cm} ; \mathrm{PG}_{4}: 100 \times 60 \mathrm{~cm} ; \quad \mathrm{NL}_{1}: 150: 30: 50: 25$ (N:P :K :Zn in kg/ha); NL $: 150: 40: 20: 24 ; \mathrm{NL}_{3}$ $: 175: 60: 60: 25 ; 1 \mathrm{Mg}=1000 \mathrm{~kg} ; \mathrm{NS}$ : non-significant difference 
Table 2: Yield and yield contributing characters of Bt cotton (Pooled mean of 2 years)

\begin{tabular}{|c|c|c|c|c|c|}
\hline \multirow[b]{2}{*}{ Nutrition levels (NL) } & \multicolumn{4}{|c|}{ Planting geometry (PG) } & \multirow[b]{2}{*}{ Mean } \\
\hline & $P_{1}$ & $\mathrm{PG}_{2}$ & $\mathrm{PG}_{3}$ & $\mathrm{PG}_{4}$ & \\
\hline & \multicolumn{4}{|c|}{ Seed cotton yield $\left(\mathrm{kg} \mathrm{ha}^{-1}\right)$} & \\
\hline $\mathrm{NL}_{1}$ & 3292 & 3115 & 3200 & 2570 & 3044 \\
\hline $\mathrm{NL}_{2}$ & 3334 & 3157 & 3504 & 2782 & 3194 \\
\hline $\mathrm{NL}_{3}$ & 3272 & 3195 & 3207 & 2833 & 3126 \\
\hline Mean & 3299 & 3155 & 3303 & 2728 & \\
\hline $\operatorname{LSD}(p=0.05)$ & \multicolumn{4}{|c|}{$\begin{array}{c}P G=263.8 ; \mathrm{NL}=\mathrm{NS} ; \mathrm{PG} \times \mathrm{NL}=\mathrm{NS} \\
\text { Lint yield }\left(\mathrm{kg} \mathrm{ha}^{-1}\right)\end{array}$} & \\
\hline $\mathrm{NL}_{1}$ & 1077 & 1038 & 1051 & 859 & 1006 \\
\hline $\mathrm{NL}_{2}$ & 1104 & 1065 & 1164 & 924 & 1064 \\
\hline $\mathrm{NL}_{3}$ & 1092 & 1112 & 1080 & 955 & 1060 \\
\hline Mean & 1091 & 1072 & 1098 & 912 & \\
\hline $\operatorname{LSD}(p=0.05)$ & \multicolumn{4}{|c|}{$\begin{array}{c}P G=95.1 ; \mathrm{NL}=\mathrm{NS} ; \mathrm{PG} \times \mathrm{NL}=\mathrm{NS} \\
\text { Seed yield }\left(\mathrm{kg} \mathrm{h}^{-1}\right)\end{array}$} & \\
\hline $\mathrm{NL}_{1}$ & 2213 & 2076 & 2150 & 1711 & 2037 \\
\hline $\mathrm{NL}_{2}$ & 2230 & 2093 & 2340 & 1858 & 2130 \\
\hline $\mathrm{NL}_{3}$ & 2178 & 2085 & 2127 & 1878 & 2067 \\
\hline Mean & 2207 & 2085 & 2205 & 1816 & \\
\hline \multicolumn{6}{|c|}{ Bolls plant ${ }^{-1}$} \\
\hline $\mathrm{NL}_{1}$ & 58.0 & 64.2 & 58.4 & 71.1 & 62.9 \\
\hline $\mathrm{NL}_{2}$ & 61.3 & 64.8 & 57.7 & 72.8 & 64.1 \\
\hline $\mathrm{NL}_{3}$ & 60.3 & 66.1 & 60.7 & 73.4 & 65.1 \\
\hline Mean & 59.8 & 65.0 & 58.9 & 72.4 & \\
\hline $\operatorname{LSD}(p=0.05)$ & \multicolumn{4}{|c|}{$\begin{array}{c}P G=3.9 ; \text { NL=NS; PG } \times \text { NL=NS } \\
\text { Boll weight }(\mathrm{g})\end{array}$} & \\
\hline $\mathrm{NL}_{1}$ & 3.44 & 3.60 & 3.52 & 3.71 & 3.57 \\
\hline $\mathrm{NI}_{2}$ & 3.47 & 3.56 & 3.54 & 3.63 & 3.55 \\
\hline $\mathrm{NL}_{3}$ & 3.47 & 3.54 & 3.47 & 3.72 & 3.55 \\
\hline Mean & 3.46 & 3.57 & 3.51 & 3.69 & \\
\hline $\operatorname{LSD}(p=0.05)$ & \multicolumn{4}{|c|}{$P G=N S ; N L=N S ; P G \times N L=N S$} & \\
\hline
\end{tabular}

Note: $P_{1}: 67.5 \times 60 \mathrm{~cm} ; \mathrm{PG}_{2}: 67.5 \times 75 \mathrm{~cm} ; \mathrm{PG}_{3}: 100 \times 45 \mathrm{~cm} ; \mathrm{PG}_{4}: 100$ x $60 \mathrm{~cm} ; \mathrm{NL}_{1}: 150: 30: 50: 25$ (N: $\mathrm{P}: \mathrm{K}: \mathrm{Zn}$ in kg ha-1); $\mathrm{NL}_{2}: 150: 40: 20: 24 ; \mathrm{NL}_{3}$ :175:60:60:25; NS: non-significant difference

observed for $\mathrm{PG}_{4}$. Fibre quality parameters too exhibited significant variations, wherein $P_{2}$ exhibited significantly highest lint (33.9\%), while $P G_{1}$ witnessed least (Table 3). $P_{4}$ exhibited lowest lint and seed index.

Though, monopods and sympods per plant were highest for $\mathrm{PG}_{4}$, however, as a result of least plant stand, biomass accumulation was significantly reduced. This might be due to the fact that being widely placed, individual plants in case of $\mathrm{PG}_{4}$ could utilize the available resources like light, nutrients and water in a better way owing to minimum inter and intra row competition for growth and development as compared to other geometries. Despite the fact that bolls per plant under $\mathrm{PG}_{4}$ remained significantly higher by $21.0,11.3$ and $22.9 \%$ compared to $P G_{1}, P G_{2}$ and $P G_{3}$, respectively, it recorded significantly low SCY by $20.9,15.6$ and $21.0 \%$ than respective geometries. The reason behind low yield performance under $\mathrm{PG}_{4}$ was its sub-optimal plant stand, which could not compete with other planting geometries owing to their high population and, consequently higher yield attributes such as bolls per plant per unit area. These findings closely match with Zhi et al. (2016) who reported that plant stand of 51000 and 87000 plants ha ${ }^{-1}$ increased lint yield by 61.3 and $65.3 \%$ in 2012 and 17.8 and $15.5 \%$ in 2013 relative to low stand of 15000 plants ha ${ }^{-1}$. Significantly reduced stand $\mathrm{ha}^{-1}$ in $\mathrm{PG}_{4}$ has remained the reason for its low yield as evident from 44.5, 19.8 and $33.4 \%$ low plant population as compared to $P G_{1}, P G_{2}$ and $P G_{3}$, respectively.

$P g_{1}, P G_{2}$ and $P G_{3}$ could exhibit only trivial differences for most of the yield attributes as well as for SCY. These studies elucidate that despite significantly improved performance in terms of attributes like sympods and bolls per plant under $\mathrm{PG}_{4}$, 
Table 3: Fibre and productivity parameters of Bt cotton (Pooled mean of 2 years)

\begin{tabular}{|c|c|c|c|c|c|}
\hline \multirow[b]{2}{*}{ Nutrition levels (NL) } & \multicolumn{4}{|c|}{ Planting geometry (PG) } & \multirow[b]{2}{*}{ Mean } \\
\hline & $P G_{1}$ & $\mathrm{PG}_{2}$ & $\mathrm{PG}_{3}$ & $\mathrm{PG}_{4}$ & \\
\hline \multicolumn{6}{|c|}{ Lint $(\%)$} \\
\hline $\mathrm{NL}_{1}$ & 32.6 & 33.3 & 32.8 & 33.4 & 33.0 \\
\hline $\mathrm{NL}_{2}$ & 33.1 & 33.7 & 33.2 & 33.2 & 33.2 \\
\hline $\mathrm{NL}_{3}$ & 33.4 & 34.8 & 33.7 & 33.6 & 33.9 \\
\hline Mean & 33.0 & 33.9 & 33.2 & 33.4 & \\
\hline \multicolumn{6}{|c|}{ Lint Index (g) } \\
\hline $\mathrm{NL}_{1}$ & 4.25 & 4.16 & 4.12 & 4.12 & 4.16 \\
\hline $\mathrm{NL}_{2}$ & 4.27 & 4.31 & 4.45 & 4.07 & 4.27 \\
\hline $\mathrm{NL}_{3}$ & 4.45 & 4.62 & 4.22 & 4.23 & 4.38 \\
\hline Mean & 4.32 & 4.36 & 4.26 & 4.14 & \\
\hline \multicolumn{6}{|c|}{$\begin{array}{c}P G=0.16 ; \text { NL=0.10; PG } \times \text { NL=NS } \\
\text { Seed index }(g)\end{array}$} \\
\hline $\mathrm{NL}_{1}$ & 8.72 & 8.33 & 8.42 & 8.23 & 8.42 \\
\hline $\mathrm{NL}_{2}$ & 8.60 & 8.48 & 8.93 & 8.18 & 8.55 \\
\hline $\mathrm{NL}_{3}$ & 8.85 & 8.68 & 8.31 & 8.34 & 8.54 \\
\hline Mean & 8.72 & 8.50 & 8.55 & 8.24 & \\
\hline \multicolumn{6}{|c|}{ Apparent water productivity $\left(\mathrm{kg} . \mathrm{m}^{-3}\right)$} \\
\hline $\mathrm{NL}_{1}$ & 0.731 & 0.692 & 0.711 & 0.571 & 0.676 \\
\hline $\mathrm{NL}_{2}$ & 0.740 & 0.701 & 0.778 & 0.618 & 0.709 \\
\hline $\mathrm{NL}_{3}$ & 0.726 & 0.710 & 0.712 & 0.629 & 0.694 \\
\hline Mean & 0.732 & 0.701 & 0.734 & 0.606 & \\
\hline \multicolumn{5}{|c|}{ Fertilizer use efficiency (kg SCY kg ${ }^{-1}$ fertilizer) } & \\
\hline $\mathrm{NL}_{1}$ & 12.90 & 12.21 & 12.54 & 10.07 & 11.93 \\
\hline $\mathrm{NI}_{2}$ & 14.24 & 13.49 & 14.97 & 11.88 & 13.64 \\
\hline $\mathrm{NL}_{3}$ & 10.22 & 9.98 & 10.02 & 8.85 & 9.77 \\
\hline Mean & \multirow{2}{*}{\multicolumn{5}{|c|}{$\begin{array}{c}11.89 \\
P G=1.13 ; N L=0.66 ; P G \times N L=N S\end{array}$}} \\
\hline LSD $(p=0.05)$ & & & & & \\
\hline
\end{tabular}

Note: $P_{1}: 67.5$ x 60 cm; PG $: 67.5$ × 75 cm; PG $: 100$ x 45 cm; PG $: 100$ x 60 cm; NL $: 150: 30: 50: 25$ (N: P: K: Zn in kg/ha); NL :150:40:20:24; NL $: 175: 60: 60: 25$; NS: non-significant difference

SCY remained least than other PG as their higher plant stand compensated for better performance of individual plant and ultimately resulted in statistically higher yield. Though, individual plant performance in terms of yield attributes like sympods and bolls per plant has been significantly better under wider than narrow planting geometry, but it was mainly higher plant population in the later case which compensated for better individual plant performance in wider spacing and consequently recorded higher SCY. Present findings get support from Narayana et al. (2007) wherein cotton grown in $120 \mathrm{~cm}$ inter rows resulted in significantly better number of bolls per plant than inter rows of $90 \mathrm{~cm}$ owing to the reasons discussed above. Reddy and Gopinath (2008) reported significant improvement in bolls per plant under wider inter rows of $90 \mathrm{~cm}$ due to least competition for the available resources among plants as compared to closer (60 and $30 \mathrm{~cm}$ inter row) spacing is in line with our results. Better boll weight and bolls per plant in case of $\mathrm{PG}_{4}$ might be also due to improved canopy aeration, better interception of solar radiation and lesser competition for available nutrient and moisture, which might have resulted in synthesis of higher photosynthates in line with Sankaranarayanan et al. (2011). Bhalerao and Gaikwad (2010) also reported that a PG of $90 \mathrm{~cm} \times 45 \mathrm{~cm}$ recorded 50.5 and $17.7 \%$ higher SCY than $90 \mathrm{~cm} \times 90 \mathrm{~cm}$ and $90 \mathrm{~cm} \times 60 \mathrm{~cm}$, respectively, though plants in wider geometry had more bolls per plant (23.1) than closer (20.8) is in agreement with our finding.

However, SCY between $P G_{1}, P G_{2}$ and $P G_{3}$ remained at par in line with Srinivasulu et al. (2006) wherein tested PG could not exert significant differences. Owing to lack of determinate growth habit, morphological differences and yield variability in response to planting geometry is quite evident in cotton (Yang et al., 2014) and this could be one of the reasons in present study wherein $P G_{1}, P G_{2}$ and $P G_{3}$ could strike a balance between population and yield attributes and resulted in similar yield in line 
Table 4: Monetary parameters of Bt cotton. (Pooled mean of 2 years)

\begin{tabular}{|c|c|c|c|c|c|}
\hline \multirow[b]{2}{*}{ Nutrition levels (NL) } & \multicolumn{4}{|c|}{ Planting geometry (PG) } & \multirow[b]{2}{*}{ Mean } \\
\hline & $P_{1}$ & $\mathrm{PG}_{2}$ & $\mathrm{PG}_{3}$ & $\mathrm{PG}_{4}$ & \\
\hline \multicolumn{6}{|c|}{ Cost of cultivation $\left(\$\right.$ ha $\left.^{-1}\right)$} \\
\hline $\mathrm{NL}_{1}$ & 665.4 & 636.2 & 650.5 & 578.3 & 632.6 \\
\hline $\mathrm{NL}_{2}$ & 669.7 & 640.5 & 678.4 & 597.9 & 646.6 \\
\hline $\mathrm{NL}_{3}$ & 695.6 & 675.7 & 683.4 & 634.4 & 672.3 \\
\hline Mean & 676.8 & 650.8 & 670.8 & 603.5 & \\
\hline \multicolumn{6}{|c|}{$\begin{array}{c}P G=24.0 ; N L=14.7 ; P G \times N L=N S \\
\text { Gross Returns }\left(\$ h^{-1}\right)\end{array}$} \\
\hline $\mathrm{NL}_{1}$ & 2093.6 & 1981.8 & 2036.5 & 1635.3 & 1936.8 \\
\hline $\mathrm{NL}_{2}$ & 2121.4 & 2010.0 & 2229.5 & 1770.1 & 2032.7 \\
\hline $\mathrm{NL}_{3}$ & 2080.8 & 2034.4 & 2041.0 & 1802.6 & 1989.6 \\
\hline Mean & 2098.6 & 2008.7 & 2102.3 & 1736.0 & \\
\hline \multicolumn{6}{|c|}{ Net Returns (US\$ ha $\left.{ }^{-1}\right)$} \\
\hline $\mathrm{NL}_{1}$ & 1428.2 & 1345.7 & 1385.9 & 1057.0 & 1304.1 \\
\hline $\mathrm{NL}_{2}$ & 1451.7 & 1369.5 & 1550.8 & 1172.2 & 1386.0 \\
\hline $\mathrm{NL}_{3}$ & 1385.1 & 1358.7 & 1357.6 & 1168.2 & 1317.4 \\
\hline Mean & 1421.7 & 1357.9 & 1431.4 & 1132.4 & \\
\hline \multicolumn{6}{|c|}{ C: B ratio } \\
\hline $\mathrm{Nl}_{1}$ & 2.13 & 2.10 & 2.13 & 1.82 & 2.05 \\
\hline $\mathrm{NL}_{2}$ & 2.16 & 2.13 & 2.28 & 1.95 & 2.13 \\
\hline $\mathrm{NL}_{3}$ & 1.99 & 2.00 & 1.98 & 1.83 & 1.95 \\
\hline Mean & 2.09 & 2.08 & 2.13 & 1.87 & \\
\hline $\operatorname{LSD}(p=0.05)$ & \multicolumn{5}{|c|}{$P G=0.14 ; N L=0.09 ; P G \times N L=N S$} \\
\hline
\end{tabular}

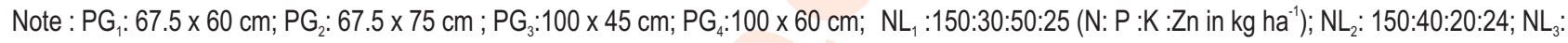
175:60:60:25; 1 US\$=66 INR; NS: non-significant difference

with Brar et al. (2008). Therefore, the present findings elucidated a similar behavior wherein $P G_{1}, P G_{2}$ and $P_{3}$ could strike a balance for similar seed cotton yield by varying their yield attributes to a considerable effect. Lint and seed yield trends also remained similar to that of SCY owing to the reasons explained above.

Among fibre parameters, $\mathrm{PG}_{2}$ exhibited higher $\mathrm{GOT}(\%)$ by $0.9,0.7$ and $0.5 \%$, over $P G_{1}, P G_{3}$ and $P_{4}$, respectively. Therefore, from the prospective of higher lint yield $P G_{2}$ maintained its edge which might be due to favorable microclimate in the crop canopy resulting into lint improvement. However, lint index remained minimum for $\mathrm{PG}_{4}$ with rest of geometries being at par. $P G_{2}$ revealed significantly better lint (\%) as compared to other geometries due to favorable combination of edaphic and microclimatic conditions. Apparent water productivity (AWP) and FUE for $\mathrm{PG}_{4}$ has been significantly low, while rest of geometries varied non-significantly. Poor values for AWP and FUE indicated that $P_{4}$ was less efficient to utilize available water and fertilizer for their conversion into economic yield. Conversely, other studied geometries could utilize available resources in a better manner leading to improved transformation of their energy into seed cotton yield. Owing to low seed cotton yield coupled with poor net returns, $\mathrm{PG}_{4}$ revealed least C: B ratio (1.87). This revealed it to be a non-remunerative option as compared to rest of the tested geometries. Better FUE and AWP indices and higher net returns for $P G_{2}$ could exhibit statistically superior $\mathrm{C}$ : B ratio (2.08) over $\mathrm{PG}_{4}$. Moreover, being hybrid nature of seed, Indian farmers have to purchase fresh $B t$ cotton seed from the market every year for sowing. Being a costly input, higher quantity of $B t$ cotton seed adds considerably to total cost of cultivation and therefore a PG which is giving higher SCY along with best lint (33.9\%) with minimum seed input shall be helpful in cutting cost of cultivation to a large extent.

From that perspective, $\mathrm{PG}_{2}$ retains superiority as compared to $P G_{1}$ and $P G_{3}$, where seed input cost is relatively high due to more plant stand $\mathrm{ha}^{-1}$ required in these geometries to achieve same yield. Planting geometry affected both apparent water productivity (AWP) as well as fertilizer use efficiency (FUE) significantly (Table 3). $\mathrm{PG}_{3}$ exhibited highest AWP closely followed by $P G_{1}$ and $P G_{2}$ while $P G_{4}$ recorded significantly least $\left(0.606 \mathrm{~kg} \mathrm{~m}^{-3}\right)$.

The trend for FUE also remained similar wherein $P_{4}$ (10.27) recorded least value with rest of the PG being at par. Among monetary parameters, the cost of cultivation per ha has 


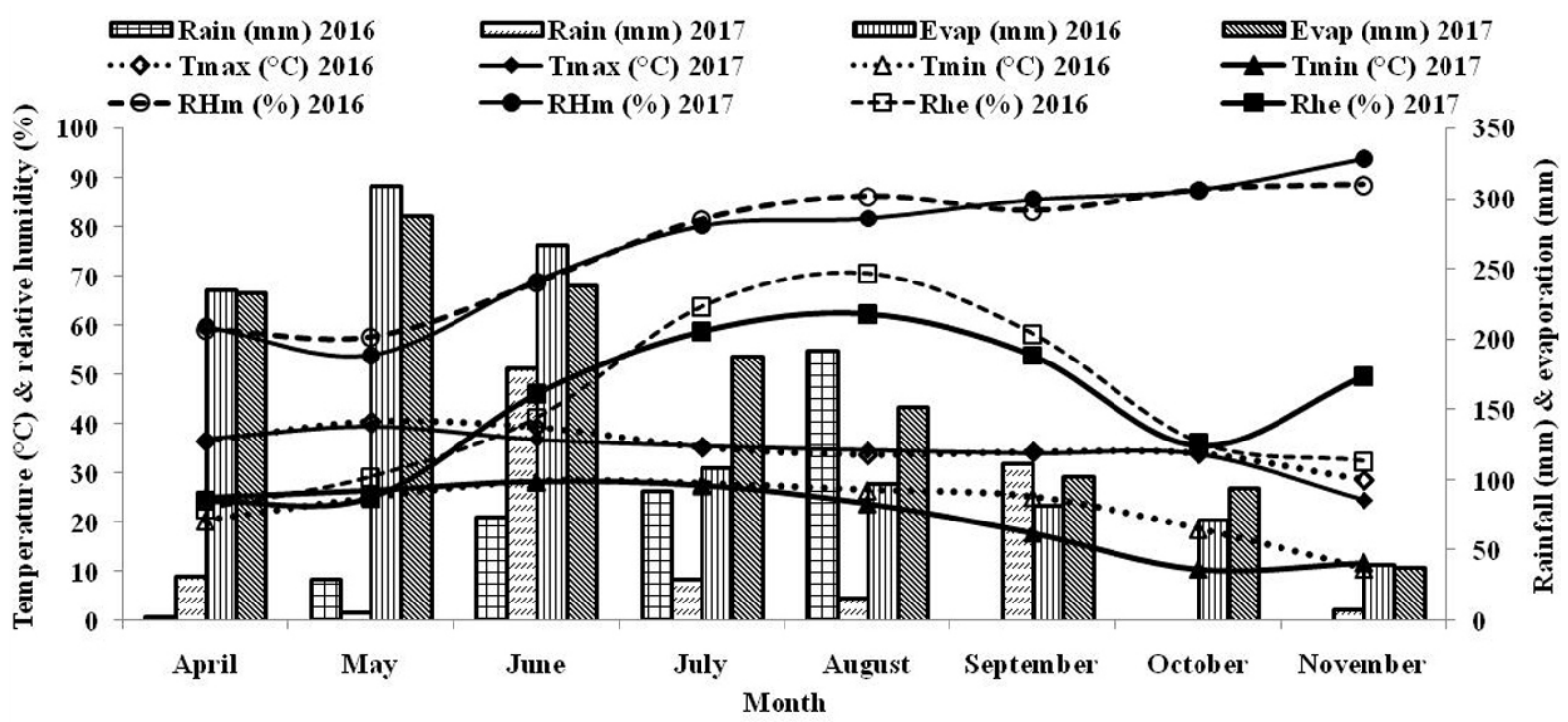

Fig. 1: Prevailing weather conditions at experimental site during crop seasons $(2016,2017)$.

been highest for $\mathrm{PG}_{1}(676.8 \$)$ but gross $(2102.3 \$)$ as well as net returns $\left(1431.4 \$\right.$ ) remained higher for $\mathrm{PG}_{3}$. Higher cost of $B t$ seed was one of the reasons attributing towards more cultivation cost in $P G_{1}$. Higher $C: B$ ratio has been observed for $P_{3}(2.13)$, though at par with $P G_{1}$ and $P G_{2}$ but significantly better than $P_{4}(1.87)$.

Adequate level of nutrition or applied fertilizer is essential to achieve the potential yield of $B t$ cotton. Defining nutritional requirement is not only crucial for better productivity but also for quality cotton. However optimum fertilizer dose varies with soil and agro climate condition. Among growth parameters, nutrient levels could exert significant effect only on sympods, while plant height, monopods, biomass and plant stand remained at par (Table 1). $\mathrm{NL}_{3}$ recorded the highest (24.4), while NL, recorded significantly lowest (22.3) sympods per plant. Various yield attributes such as boll weight, seed and lint yield exhibited only non-significant variations (Table 2). Bolls per plant increased from 62.9 to 64.5 and then to 65.1 for $\mathrm{NL}_{1}, \mathrm{NL}_{2}$ and $\mathrm{NL}_{3}$, respectively, but with only trivial differences. Consequently, SCY among tested nutrition levels remained at par with a value of 3044,3194 and $3126 \mathrm{~kg} \mathrm{ha}^{-1}$ for $\mathrm{NL}_{1}, \mathrm{NL}_{2}$ and $\mathrm{NL}_{3}$. Though, $\mathrm{NL}_{2}$ revealed $4.92 \%$ and $2.17 \%$ higher SCY than $\mathrm{NL}_{1}$ and $\mathrm{NL}_{3}$ respectively. Among other parameters, only lint index was affected significantly with higher value under $\mathrm{NL}_{3}(4.38 \mathrm{~g})$ whereas lint (\%) and seed index varied non-significantly (Table 3). The trend for lint index was $\mathrm{NL}_{3}>\mathrm{NL}_{2}>\mathrm{NL}_{1}$. Among nutrient levels, only sympods per plant exhibited improvement under $\mathrm{NL}_{3}$, but boll weight and bolls per plant and $\mathrm{SCY}$ remained at par. Bolls per plantimproved non-significantly from 62.9 to 64.1 and then declined to 65.1 for $\mathrm{NL}_{1}, \mathrm{NL}_{2}, \mathrm{NL}_{3}$, respectively. This implies that there is no need to go for higher fertilizer doses as applied under $\mathrm{NL}_{3}$, as it could not result in significant yield increments. Moreover, additional expenditure incurred on elevated levels of fertilizer is adding to higher cultivation cost. Higher yield due to improvement in bolls per plant under enhanced levels of nutrients has also been reported by Sunitha et al. (2010) but in present study none of the yield attributes could gain any superiority due to additional fertilizer applied. Therefore, adding fertilizer without monetary benefits would only increase cultivation cost.

Thus current findings clearly elucidate that nutrition requirement of each $B t$ cotton hybrid is unique depending on the fertility status of soil in a particular agro-climatic zone. Our findings closely match with Dong et al. (2012) who observed that under low plant density, high $\mathrm{N}$ dose is a must to achieve better lint yield (1604 kg ha-1), while similar yields (1693 and $1643 \mathrm{~kg} \mathrm{ha}^{-1}$ ) can also be obtained with moderate and low $\mathrm{N}$ rate under medium and high plant population (Rochester, 2012). These findings give fair support in the present case, where application of higher nutrition could not make any difference. Except for lint index, all quality parameters varied nonsignificantly in different nutrition levels is in conformity with Dadgale et al. (2014). Water productivity $\left(\mathrm{kg} \mathrm{m}^{-3}\right)$ also improved non-significantly from 0.676 to 0.709 under $\mathrm{NL}_{1}$ and $\mathrm{NL}_{2}$, and further witnessed a decline there after for $\mathrm{NL}_{3}(0.694)$. However, Singh et al. (2014) observed a significant improvement in water productivity $\left(0.710 \mathrm{~kg} \mathrm{~m}^{-3}\right)$ with improved nutrition in $B t$ cotton over that of control $\left(0.491 \mathrm{~kg} \mathrm{~m}^{-3}\right)$. Contrarily, FUE followed the reverse trend, as it improved from $11.93\left(\mathrm{NL}_{1}\right)$ to $13.64\left(\mathrm{NL}_{2}\right)$ and then declined to a significantly least (9.77) for $\mathrm{NL}_{3}$. This indicated $\mathrm{NL}_{2}$ to be a better option from FUE perspective, as it exhibited significantly higher efficiency in line with Rochester (2012). 
These findings can be beneficial to formulation of a scientific and rational package for usage of nutrients in sustainable cotton production in line with Luo et al. (2018). Cost of cultivation has been remarkably escalated with each successive increase in nutrient levels, though gross and net returns remained at par is in agreement with Nagender et al. (2017) who could not achieve significant effect of varied nutrition levels on gross and net returns. Contrarily, Biradar et al. (2010) observed better monetary returns in cotton grown under elevated level of nutrition $(150 \%)$ than $100 \%$ recommended level which strengthens the fact that response varies with soil fertility status, irrigation and cultivation practices. Owing to significantly better FUE coupled with higher net returns, $\mathrm{NL}_{2}(2.13)$ could exhibit superior $\mathrm{C}$ : $\mathrm{B}$ ratio over $\mathrm{NL}_{3}(1.95)$. FUE and $\mathrm{C}$ : $\mathrm{B}$ ratio remained in favor of $\mathrm{NL}_{2}$ which implied it to be the better option among tested levels. Among efficiency indices, only FUE could exhibit significant difference while AWP revealed trivial differences (Table 3). AWP $\left(\mathrm{kg} \mathrm{m}^{-3}\right)$ values increased from $\mathrm{NL}_{1}$ to $\mathrm{NL}_{2}$ and then a decline was observed for $\mathrm{NL}_{3}$, though differences remained trivial. Among monetary parameters, the cost of cultivation and $\mathrm{C}: \mathrm{B}$ ratio revealed significant differences for $\mathrm{NL}$, while gross as well as net returns could not mark any significant effect. Cultivation cost per hectare has been significantly higher under $\mathrm{NL}_{3}(672.3 \$)$, followed by $\mathrm{NL}_{2}(646.6 \$)$ and least for $\mathrm{NL}_{1}$ (632.6 \$) but despite that gross and net returns remained at par. Higher C: B ratio was observed under $\mathrm{NL}_{2}$ (2.13) though it was at par with $\mathrm{NL}_{1}$ but significantly better than $\mathrm{NL}_{3}$. Statistically least $\mathrm{C}$ : $\mathrm{B}$ (1.95) was recorded under $\mathrm{NL}_{3}$ (Table 4).

From the present findings it can be concluded that both production and productivity in north-western India can be improved by adopting ideal planting geometry with optimum nutritional inputs. $P_{2}(67.5 \mathrm{~cm} \times 75 \mathrm{~cm})$ and a nutrition level $\mathrm{NL}_{2}$ (150:40:20:24 N:P: K: Zn in kg ha ${ }^{-1}$ ) revealed better productivity of evaluated Bt cotton hybrid (RCH650BGII) which might be due to fair redistribution of applied nutrients from vegetative organs to reproductive sink, i.e., developing bolls. Monetary benefit alone as evident from $\mathrm{C}$ : $\mathrm{B}$ ratio is sufficient enough to promote the widespread adoption of $\mathrm{PG}_{2}$ and $\mathrm{NL}_{2}$. No yield advantages accrued beyond $\mathrm{NL}_{2}$ level which indicated that farmers can save money by avoiding $\mathrm{NL}_{3}$ without sacrificing yield. Our findings elucidate that nutrition rates could be further reduced by $86 \mathrm{~kg}$ ha $^{-1}$ (i.e $25: 20: 40: 1 \mathrm{~kg}$ of $\mathrm{N}, \mathrm{P}, \mathrm{K}$ and $\mathrm{Zn}$ ) which amount to $33 \$$ $\mathrm{ha}^{-1}$ from what farmers are applying, without any yield loss. The results of present findings can potentially save money of cotton growers by saving nearly 0.13 million ton of the fertilizer for entire north-western India comprising cotton acreage of $\sim 1.54$ million ha. Also, growers must realize that planting at wider geometry $\left(\mathrm{PG}_{4}\right)$ by using low seed rate to save little money shall not be remunerative as net returns decline sharply. These findings can be utilized for formulation of a scientific and judicious schedule for nutrient application and sustain cotton productivity under similar environments.

\section{References}

Anonymous: All India co-ordinated research project on cotton-Annual Report (2017-18) http://aiccip.cicr.org.in/CD_17-8/3_ A1_A17_ PC_report.pdf,A1-A17 (2017).

Anonymous: Punjab could see more areas under cotton cultivation. https://www.thehindu.com/news/national/other-states/punjabcould-see-more-areas-under-cotton-cultivation/ article 31440214. ece (2020).

Bhalerao, P.D. and G.S. Gaikwad: Productivity and profitability of Bt cotton (Gossypium hirsutum) under various plant geometry and fertilizer levels. Ind. J. Agron., 55, 60-63 (2010).

Biradar, V., S. Rao and V. Hosamani: Economics of late sown Bt cotton as influenced by different spacing, fertilizer and NAA applications under irrigation. Int. J.Agric. Sci., 6,196-198 (2010).

Brar, S.K., S.S. Mahal, A.S. Brar, K.K. Vashist, N. Sharma and G.S. Buttar: Transplanting time and seedling age affect water productivity, rice yield and quality in north- west India. Agric. Water Manage., 115, 217-222 (2012).

Brar, J.S., B.S. Sidhu, K.S. Sekhon and G.S. Buttar: Response of Bt cotton to plant geometry and nutrient combinations in sandy loam soil. J. Cotton Res. Dev., 22, 59-61 (2008).

Dadgale, P.R., D.A. Chavan, B.A. Gudade, S.G. Jadhav, V.A. Deshmukh and S. Pal: Productivity and quality of Bt cotton (Gossypium hirsutum) as influenced by planting geometry and nitrogen levels under irrigated and rainfed conditions. Ind. J. Agric. Sci., 84, 1069-1072 (2014).

Dong, H., X. Kong, W. Li, W. Tang and D. Zhang: Effects of plant density, nitrogen and potassium fertilization on cotton yield and uptake of major nutrients in two fields with varying fertility. Field Crops Res., 119, 106-113 (2010).

Dong, H., W. Li, E. Anthony and D. Zhang: Nitrogen rate and plant density effects on yield and late-season leaf senescence of cotton raised on a saline field. Field Crops Res., 126,137-144 (2012).

Khan, A., W. Leishan, A. Saif, A.T.H. Shahbaz and Y. Guozheng: Optimal planting density and sowing date can improve cotton yield by maintaining reproductive organ biomass and enhancing potassium uptake. Field Crops Res., 214,164-174 (2017).

Luo, Z., H. Liu, W. Li, Q. Zhao, J. Dai, L. Tian and H. Dong: Effects of reduced nitrogen rate on cotton yield and nitrogen use efficiency as mediated by application mode or plant density. Field Crops Res., 218, 150-157 (2018).

Nagender, T., D. Raji Reddy, P. Leela Rani, G. Sreenivas, K. Surekha, A. Gupta and P.D. Sreekanth: Productivity of Bt and Non Bt cotton (Gossypium hirsutum L.) cultivars as influenced by plant geometry and fertilizer levels. Int. J. Curr. Micro. Appl. Sci., 9, 3208-3217 (2017).

Narayana, E., K. Hema, K. Srinivasulu, N.V.V.S.D. Prasad and N.H.P. Rao: Agronomic evaluation of Gossypium hirsutum hybrids for varied spacings and nitrogen levels in vertisols under rainfed conditions. J. Cotton Res. Dev., 21, 197-200 (2007).

Reddy, P.R. and M. Gopinath: Influence of fertilizers and plant geometry on performance of Bt cotton hybrid. J. Cotton Res. Dev., 22, 78-80 (2008).

Rochester, I.J.: Using seed nitrogen concentration to estimate crop N use efficiency in high yielding irrigated cotton. Field Crop Res., 127, 140-145(2012).

Sankaranarayanan, K., C.S. Praharaj, P. Nalayini and N. Gopalakrishnan: Growth, yield and quality of Bt cotton (Gossypium hirsutum) hybrid under varied planting patterns, NPK levels and seasonal variations. Ind. J. Agric. Sci., 81, 871-874 (2011).

Shukla, U.N., M.S. Khakare, S. Singh and S.K. Verma: Effect of crop 
geometries and fertility levels on growth, yield and residual nutrients of cotton (Gossypium hirsutum) hybrids under rainfed condition. Ind. J. Agric. Sci., 84, 780-783 (2014).

Singh, K., A.S. Brar and H.P. Singh: Drip fertigation improves water and nitrogen use efficiency of Bt cotton. J. Soil Water Cons., 73, 549-557 (2018).

Singh, K., O.P. Choudhary, H.P. Singh, A. Singh and S.K. Mishra: Subsoiling improves productivity and economic returns of cottonwheat cropping system. Soil Tillage Res., 189, 131-139 (2019).

Singh, K., H.P. Singh and S.K. Mishra: Irrigation module and sowing date affect seed cotton yield, quality, productivity indices and economics of cotton in North-western India. Comm. Soil Sci. Plant Analysis, 51,919-931 (2020).

Singh, K., P. Rathore and R.K. Gumber: Productivity potential and monetary evaluation of $\mathrm{Bt}$ cotton hybrids under varied agronomic manipulations in semi-arid conditions. J. Environ. Biol., 35, 839-842 (2014).

Srinivasulu, K., K. Hema, N.V.V.S.D. Prasad and K.V. Rao: Performance of cotton hybrids under different spacings and nitrogen levels in black cotton soils of coastal Andhra Pradesh. J. Cotton Res. Dev., 20,99-101 (2006).

Sunitha, V., K. Chandrasekhar and R. Veeraraghavaiah: Performance of Bt cotton hybrids at different nitrogen levels. J. Cotton Res. Dev., 24,52-55 (2010).

Yang, G.Z., X.J. Luo, Y.C. Nie and X.L. Zhang : Effects of plant density on yield and canopy micro environment in hybrid cotton. J. Integ. Agric., 13, 2154-2163 (2014).

Zhi, X., Y. Han, Y. Li, G.D. Wang, W. Li, X. Mao and S.F. Lu: Effects of plant density on cotton yield components and quality. J. Integ. Agric., 15,1469-1479 (2016). 